\title{
Revize Edilen Hemşirelerin Mesleki Değerleri Ölçeği Türkçe Formunun Güvenirlik ve Geçerliği
}

\author{
Reliability and Validity of Turkish Version of the Nurses Professional Values \\ Scale-Revised
}

\author{
Rengin ACAROĞLU*
}

İletişim/Correspondence: Rengin ACAROĞLU Adres/Adress: İ.Ü. Florence Nightingale Hemşirelik Fakültesi, Abide-i Hürriyet Cad. 34381 Şişli/İstanbul Tel: 02124400000 / 27004 Fax: 02122244990 E-mail: rencar@istanbul.edu.tr

\section{$\ddot{O} Z$}

Amaç: Çalışma, revize edilen Hemşirelerin Mesleki Değerleri Ölçeğinin (Nurses Professional Values Scale - Revised) Türkçe formunun geçerlik ve güvenirliğini incelemek amact ile gerçekleştirildi.

Yöntem: Metodolojik araştırma tipinde planlanan çalışmanın örneklemi228 hemşire ve hemşirelik ögrencisinden oluştu. Ölçeğin dil eşdeğerliği çeviri-geri çeviri teknikleri kullantlarak sağlandı. Veriler bilgi formu ve Türkçe HMDÖ-Rile topland. Kapsam geçerliği için alınan uzman görüşleri Kapsam Geçerlik Indeksi ile değerlendirildi. Ölçeğin güvenirliği için zamana göre değişmezliğine bakıldı ve iç tutarlılı̆̆ Cronbach Alfa Katsayısı ve madde analizi ile incelendi. Ölçĕ̆in yapı geçerliği varimaks rotasyonu uygulanarak açımlayıcı faktör analizi ile yapıldı.

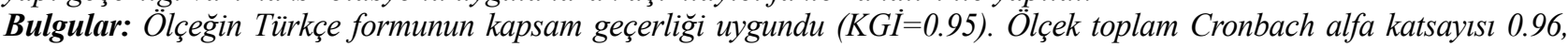
madde toplam puan korelasyonlarl 0.47 ile 0.79 arasinda, test-tekrar test güvenirlik katsayıs 0.90 bulundu. Faktör analizi sonucu ölçek, özgün ölçekten farkl, tek boyutlu ve toplam varyansın \% 66.42 ssini açılayan üç faktörlü yapı gösterdi. Yapı geçerliği, 0.49-0.82 faktör yükü aralı̆̆ ile desteklendi. Faktörler Bakım verme, Profesyonellik ve Güven olarak isimlendirildi.

Sonuç: Hemşirelerin Mesleki Değerleri Ölçeği-Revize'nin Türk toplumuna uyarlanmast için yapılan analizlerden elde edilen bulgular, ölçeğin Türkçe formunun, hemşirelik değgerlerinin incelenmesinde tek boyutlu bir araç olarak, güvenilir ve geçerli olduğunu gösterdi.

Anahtar Kelimeler: Mesleki değerler, hemşirelik, geçerlik, güvenirlik.

\begin{abstract}
Aim: This study was conducted to examine the validity and reliability of the Turkish version of the Revised Nursing Professional Values Scale (NPVS-R).

Method: The study planned methodologically was conducted with 97 nurses and 228 nursing students. The semantic equivalence of the scales were obtained using forward-back translation techniques. The data was collected with a questionnaire and the Turkish version of the NPVS-R. Expert opinions for content validity was assessed by Content Validity Index.Construct validity of the scale was analyzed with principal component factor analysis with varimaks rotation. Reliability of the scale was determined with the test-retest reliability and, Cronbach's alpha coefficients and item analysis for internal consistency. Results: The Turkish version of the scale had good content validity (CVI=0.95). The scale total cronbach alpha coefficient was found 0.96, and test-retest reliability coefficient 0.90, and item-total correlation coefficient was found between 0.47 to 0.79 . The factor analysis results demonstrated in a three-factor solution explaining $66.42 \%$ of the total variance that was different from the original scale. Construct validity was supported with an overall factor loading range of 0.49-0.82. The factors labeled as Caring, Professionalism and Trust.

Conclusion: The findings of analyzes carried out for the adaptation of the Turkish community of the Nurses Professional Values Scale, the Turkish version of the scale showed that reliable and valid as unidimensional a tool in examining of the nursing values. Key Words: Professional values, nursing, reliability, validity.
\end{abstract}

*** Doç. Dr. Istanbul Üniversitesi Florence Nightingale Hemşirelik Fakültesi

Yazının gönderilme tarihi: 08.04.2013

Yazının basım için kabul tarihi: 10.01.2014 


\section{GíRiş}

Değerler genel anlamda bir amaç, obje, ilke ya da davranış hakkındaki inanç ve tutumlardır. Diğer bir değişle değer, bireysel ve toplumsal olarak yaşamı anlamlandırma biçimine göre tercih edilen bir davranış normu ya da yaşam amacı biçimindeki kalıcı bir inançtır. İnsan yaşamındaki ideallere işaret eden değerler, bir taraftan birey, grup ya da toplum için önemli olan şeyin anlamını ifade ederken diğer taraftan kişiye, aidiyet duygusu ile birlikte bir kimlik yüklerler (Kuçuradi 2002; Milton 2007). Bu anlamda her birey yaşamına anlam katan, yaşamını biçimlendiren ve yönlendiren kişisel, sosyal/toplumsal/kültürel ve mesleki değerlere sahiptir. Bireyde, farklı kaynaklardan kökenini alan bu değerler, "değer sistemi" olarak nitelendirilen ve birbiri ile sürekli etkileşim içinde olan hiyerarşik bir değer örüntüsü oluştururlar (Babadağ 2010; Pakizeh, Gebauer ve Maio 2007).

Mesleki değerler, eylemleri ve amaçları yargılamada temel bir standart sağlayan ve meslek üyelerinin güçlü duygusal bağl1lıklarıyla oluşmuş, soyut ve genelleştirilmiş davranış ilkeleri olup mesleki etik kodlarda sözel olarak ifade bulurlar (Snellman ve Gedda 2012). Hemşirelerin mesleki değerleri hemşirelerin bakım eylemlerini uygulamalarında, kararlarında ve etik sorunları çözümlemelerine rehberlik ederken aynı zamanda sağliklı/hasta bireyler, meslektaşları, diğer ekip üyeleri ve toplum ile etkileşimlerine de rehberlik ederler. Mesleki değerlerin içselleştirilmesi, çatışmaları çözümleme ve öncelikli eylemleri belirleme yeterliği kazandırarak, güvenli, kaliteli ve etik bir bakımın sürdürülmesini sağlar (Babadağ 2010; Martin, Yarbrough ve Alfred 2003).

Mesleki değerler, ortak bir hemşirelik ideolojisi ve misyonunu tanımlama, mesleki uygulamalara anlam kazandırma, öğrencileri ve hemşireleri ortak bir kültürde birleştirme olanağı sağlar (Shaw ve Degazon 2008; Weis ve Schank 2002). Mesleki değerlerin aktarılması ve öğrenilmesinde eğitim süreci bir başlang1c1 oluşturur ve öğrencilerin mezuniyet sonrası mesleki sosyalleşme sürecinde bu gelişim devam eder. Eği- timde sosyalleşme süreci kişisel değerlerin biraz değişimini ve yeni profesyonel hemşirelik değerlerinin anlaşılarak kavranmasını ve benimsenmesini içerir (Fahrenwald ve ark. 2005; Schank ve Weis 2001). Öğrencilerde mesleki değerlerin oluşumu hemşirelik eğitiminin bilişsel ve duyuşsal alanlarına özgü bilgi ve becerilerdir.

Literatürde hemşirelerin ve öğrencilerin mesleki değerlere ilişkin alg1 ve davranışlarının değerlendirilmesinin önemi vurgulanmaktadır (LeDuc ve Kotzer 2009; Schank ve Weis 2000; Weis ve Schank 2000). Mesleki değerlerin incelenmesi ile elde edilecek sonuçların, bu değerlerin içselleştirilmesine yönelik eğitim ve uygulamalara rehberlik edeceği ve daha etkin stratejilerin geliştirilmesi için yararlı bilgiler sağlayacağı öngörülmektedir (Fahrenwald ve ark. 2005; Weis ve Schank 2009). Bu doğrultuda geçerli ve güvenilir araçlara gereksinim vardır ve Hemşirelerin Mesleki Değerleri Ölçeği-Revize (HMDÖ-R) mesleki değerleri ölçmek amacı ile geliştirilen bir araçtır.

\section{Hemşirelerin Mesleki Değerleri Ölçeği-Revize'nin Kuramsal Temeli ve Yapısı (Nurses Professional} Values Scale - Revised)

Hemşirelerin Mesleki Değerleri Ölçeği, hemşirelerin ve öğrencilerin mesleki değerlerinin gelişimini değerlendirmek amacı ile 2000 yılında Weis ve Schank tarafından geliştirilmiştir. Ölçeğin kuramsal çerçevesi, etik kodlar, değerler ve hemşirelik mesleki değerlerinin gelişimine ilişkin literatür taraması ile eleştirel bir yoruma dayandırılarak kavramsallaştırılmış ve Amerikan Hemşireler Birliği Hemşirelik Etik Kodları temel alınarak tasarlanmıştır. Yazarları buna yönelten öngörü, hemşirelerden mesleğin idealleri ve ahlaki normlarına uymalarının beklenmesidir. Mesleki değerler, meslek aday ve üyelerinin kalıcı olarak öğrenmesi ve içselleştirmesi gereken inançlarla mesleğin ideallerine yönlendiren, etik kodlar ise bu ideale ulaşmada mesleğin ahlaki normlarını yansıtan ve aynı zamanda içeriğinde mesleki değerleri de barındıran yegane rehberlerdir (Schank ve Weis 2000). Bu doğrultuda, hemşirelerin ve öğrencilerin mesleki değerleri benimseme 
durumlarının ölçülmesi, bir anlamda onların hemşirelik etik kodlarına verdikleri öneme ilişkin bir görüş kazandıracaktır. Nitekim bu gerekçeden yola çıkılarak Hemşirelerin Mesleki Değerleri Ölçeği, ANA Etik Kodlarının ifadeleri ile ilişkilendirilmiştir. Alt boyut olarak nitendirilmemekle birlikte, Hemşirelerin Mesleki Değerleri Ölçeği'nin her bir maddesi, özel bir etik kodu yansıtan ve yorumsal olarak açıklayan kısa tanımlayıcı cümlelerden oluşmaktadır.

Ölçek, hem eğitim hem de uygulama alanlarında kullanılabilen bir değerlendirme aracıdır. Ölçeğin ilk versiyonu 44 madde içerir. Bu uzun versiyon Orak ve Alpar (2012) tarafindan,"Hemşirelerin Mesleki Değerleri Ölçeği” olarak Türk toplumuna uyarlanmıştır.2006 yılında Weis ve Schank ölçeği yeniden gözden geçirerek revize etmişlerdir. Bu revizyona, 2001 yılında ANA Etik Kod ifadelerinde yapılan değişiklikler nedeni ile gereksinim duyan Weis ve Schank, ölçekteki 11 maddeyi değiştirmeden bırakırken 11 maddeyi yeniden düzenlemiş, 18 maddeyi çıkarmış ve ölçeğe dört yeni madde eklemiştir. Revizyon sonras 26 maddeden oluşan Hemşirelerin Mesleki Değerleri ÖlçeğiRevize'nin (HMDÖ-R) psikometrik özellikleri test edilerek yayınlandıktan sonra farklı toplumlara uyarlanarak, hemşirelerin ve öğrenci hemşirelerin mesleki değerlerini inceleyen çalışmalarda kullanılmıştır (Hoyuelos ve ark. 2010; Lin ve Wang 2010).

\section{YÖNTEM}

\section{Araştırmanın Amacı ve Türü}

Bu çalışma, Hemşirelerin Mesleki Değerleri ÖlçeğiRevize'nin (HMDÖ-R-Professional Nurses Values Scale - Revised) Türkçe formunun geçerlik ve güvenirliğini incelemek amacı ile metodolojik türde planlandi.

\section{Araştırmanın Evren ve Örneklemi}

Araştırmanın evreni, Mayıs- Haziran 2008 tarihleri arasında bir devlet üniversitesinin hemşirelik yüksekokulu öğrencileri ile aynı üniversitenin bir uygulama hastanesinin iki farklı biriminde çalışan hemşire- lerden oluştu. Örneklem grubu amaçlı örnekleme yöntemi ile belirlendi. Hasta bakımı sorumluluğu yoğun olduğu düşünülen iç hastalıkları ve cerrahi hastalıkları birimlerinde görev yapan 97 hemşire ile etik dersini almış üçüncü ve dördüncü sınıf öğrencilerinden 131 öğrenci gönüllülük ilkesi doğrultusunda çalışmaya dahil edilerek örneklem grubu oluşturuldu. Toplam 228 örneklem sayısı ile, metodolojik araştırmalarda örneklem hacminin hesaplanmasında, ölçek madde sayısının 5- 10 kat büyüklüğüne ulaşılmış olması koşulu karşılandi.

\section{Veri Toplama Araçları}

Çalışma verileri, tamamlanması yaklaşık 10 dakika süren, görüşme formu ve dil geçerliği yapılan HMDÖ-R olmak üzere iki formla toplandı.

Görüşme Formu: $\mathrm{Bu}$ form ile hemşirelerin ve öğrencilerin yaş, cinsiyet, medeni durum gibi demografik özelliklerine ilişsin veriler elde edildi.

Hemşirelerin Mesleki Değerleri Ölçeği-Revize: Hemşirelerin ve hemşirelik öğrencilerinin mesleki değerlerleri algılama düzeyini belirlemek üzere Weis ve Schank (2009) tarafından, beşli likert tipte (1-önemli değil, 2-biraz önemli, 3-önemli, 4-çok önemli, 5-çok fazla önemli) geliştirilmiş, 26 madde içeren bir ölçektir. Ölçeğin toplam puanı, yanıtlara karşılık gelen sayısal değerlerin toplanması ile elde edilir. Ölçekte ters çevrilerek puanlanan madde bulunmamaktadır. Ölçekten alınabilecek toplam puanlar 26-130 arasındadır. Yüksek puan mesleki değerlere uyumun güçlü olduğunu gösterir. HMDÖ-R alt boyut içermemektedir.

Weis ve Schank (2009), original ölçeğin psikometrik özelliklerini test ettikleri çalışmada Cronbach's alfa katsayısını 0.92 bulmuştur. Aynı çalışmada, ölçeğin, faktör yük değeri 0.46-0.79 aralığında değişen beş faktör ile desteklendiği saptanmış ve bunlar Bakım, Aktivizm, Güven, Profesyonellik ve Adalet olarak isimlendirilmiştir.

Dil Uyarlaması: Öncelikle HMDÖ-R'nin dil geçerliği sağlandı. Ölçeğin İngilizce formunun Türkçe’ye 
uyarlanmasında, literatürde önerilen ve farklı dillerdeki araçların çeviri ve uyarlaması için yaygın olarak kabul edilen çeviri-geri çeviri tekniği kullanıldı (Aksayan ve Gözüm 2002; Ercan ve Kan 2004; Erefe 2002). Bu amaçla özgün ölçek, profesyonel çevirmen olarak çalışan iki kişiye verilerek Türkçe'yeçevirisi yaptırıld1. Türkçe'ye çevirilen form araştırmacı ve iyi derecede İngilizce bilen bir öğretim üyesi tarafından incelenerek her madde için en uygun çeviri benimsendi. $\mathrm{Bu}$ aşamadan sonra Türkçe ölçeğin profesyonel bir dil uzmanı tarafından İngilizceye geri çevirisi yapıldı. Özgün ölçek ile geri çevirisi yapılan ölçekteki maddeler karşılaştırıldı ve anlamsal eşdeğerlik sağlandı (Ercan ve Kan 2004; Erefe 2002; Polit ve Beck 2004).

\section{Verilerin Analizi}

Veriler, bilgisayar ortamında SPSS 15.0 paket programı ile analizi edildi. Örneklem grubunun demografik özellikleri ve ölçek yanıtları tanımlayıcı istatistikler ile değerlendirildi. Kapsam geçerliği için Kapsam Geçerlik İndeksi (KGI) kullanıldı. Yapı geçerliği için varimaks rotasyonu ile Açımlayıcı Faktör Analizi (Principal Compenent Analysis) yapıldı. Verilerin faktör analizi için uygunluğu Kaiser_Meyer-Olkin (KMO) değeri ve Barlett's testi ile incelendi. İç tutarlılık için Cronbach Alfa Katsayısı hesaplandı. Madde toplam puan korelasyonu ve zamana göre değişmezlik için Pearson Korelasyon Analizi yapıldı. Grup ortalamalarının karşılaştırılması için t testi kullanıldı.

Kapsam Geçerliği : Kapsam geçerliği, ölçme aracında bulunan maddelerin ölçme amacına uygun olup olmadığı, ölçülmek istenen alanı temsil edip etmediğini belirlemek amacı ile uzman görüşlerinin alınmasıdır (Yurdagül 2005). Dil uyarlaması yapılan ölçeğin Türkçe formu ile birlikte İngilizce formu, dil ve kapsam geçerliği açısından uygunluğunun belirlenmesi için 10 hemşire öğretim üyesinin görüşüne sunuldu. Uzman görüşlerinin değerlendirilmesi için öğretim üyelerinden her bir maddeyi 1 “ uygun değil”, 2 “ biraz uygun (maddenin ve ifadenin uygun şekle getirilmesi gerekli)", 3 "uygun (ancak ufak değişiklikler gerekli)", 4 "çok uygun" şeklinde puan vererek değerlendirmele- ri istendi. Yapılacak yüzdelik değerlendirmede, ölçek maddelerinin \%80'inin uzmanlar tarafindan "uygun" veya "çok uygun" şeklinde değerlendirilmesi beklendi (Erefe 2002; Polit ve Beck 2004).

Güvenirlik: Ölçeğin taşıması gereken özelliklerden birisi olan güvenirlik, bir ölçme aracıyla aynı koşullarda tekrarlanan ölçümlerden elde edilen ölçüm değerlerinin kararlılığının bir göstergesidir. Çalışmada ölçeğin güvenirliği, iç tutarlık (Cronbach alfa ve madde analizi) katsayıları ve zamana göre değişmezliği incelenerek yapıldı.

Cronbach alfa katsayısı, Likert tipi ölçeklerin güvenilirliğinin sınanmasında sık kullanılan ve ölçme arac1 içinde bulunan maddelerin iç tutarlığının bir ölçüsüdür. Cronbach alfa katsayısının kültürlerarası ölçek uyarlamada, genel olarak 0.70 üzeri yeterli görülmekle birlikte 0.85-0.95 aralığının daha uygun olduğu belirtilmektedir (Gözüm ve Aksayan 2003). Madde analizi ise ölçme aracındaki her bir maddenin aldığı değer ile ölçme aracının tümünden alınan toplam değer arasındaki ilişkiyi ifade eden bir korelasyon analizidir. Korelasyon katsayısı ne kadar yüksek ise o maddenin ölçülmek istenen nitelikle ilişkisi o derece yüksektir. Madde toplam korelasyonunun yorumlanmasinda değeri .30 ve üzerinde olan maddeler ise yeterli kabul edilir Bir maddenin toplam puanla düşük ilişki göstermesi o maddenin ölçekteki diğer maddelerden farklı bir niteliği ölçtüğünü dolayısı ile güvenilir olmadığını düşündürür ve ölçekten çıkarılır (Büyüköztürk 2008; Ercan ve Kan 2004).

HMDÖ-R'nin zamana karşı değişmezliğini değerlendirmek için önerilen ve en sık kullanılan, test-tekrar test sonuçları karşılaştırıldı. İki uygulamadan elde edilen ölçüm değerleri korelasyon katsayısı, ölçeğin güvenirlik katsayısıdır. Korelasyon katsayısı (r) 0-1 arasinda değerler alabilir (Ercan ve Kan 2004). Yüksek korelasyon katsayısı, testten elde edilen ölçümlerin kararlılığına ve iki uygulama arasındaki zaman içinde ölçülen nitelikte fazla bir değişme olmadığına işaret eder. İki ölçme arasındaki zamanın ise iki ile dört hafta arasında olması gerektiğibelirtilir (Bademci 2006; 
Erefe 2002). Testin tekrarı hemşirelik öğrencilerine iki hafta sonra uyguland.

\section{Yapı Geçerliği: Ölçeğin yap1 geçerliği Açımlayıcı} Faktör Analizi kullanılarak değerlendirildi. Bu çalışmada, faktörlerin birbirleri ile ilişkili olduğu düşünülmediği için varimaks rotasyonu uygulandı (Weis ve Schank 2009). Faktör analizinde rotasyon, maddelerin hangi bileşene ait olduğuna karar vermenin zorlaştığ durumlarda açıklanan varyansı bozmadan; daha okunabilir veya daha uygun bir faktör yapısı bulabilmek için kullanılan bir yöntemdir. (Büyüköztürk 2002; Ercan ve Kan 2004). Çalışmada, faktör analizinin yor- danmasında, en uygun yapı ve doğru faktör sayısına ulaşmak için özdeğerin 1 ve üstü olması, faktör yükünün en az 0,40 olması, varyansı açıklama oran1nın 0,40 ve üzerinde olması ölçütleri esas alındı. (Erefe 2002; Polit ve Beck 2004). Analiz öncesi KMO ve Barlett testleri uygulandi. KMO testi, kısmi korelasyonların küçük olup olmadığını, dağılımın faktör analizi için yeterli olup olmadığını test etmek için uygulanan bir yöntemdir. KMO katsayısı 1'e yaklaştıkça verilerin analize uygun olduğu, 1 olmasında ise mükemmel bir uyum olduğu anlamına gelmektedir (Büyüköztürk 2004). Barlett's testi ise verilerin çok değişkenli normal dağılımdan gelip gelmediğini kontrol etmek

Tablo 1. Madde Toplam Puan Korelasyonları ve Cronbach Alfa Değerleri

\begin{tabular}{|c|c|c|c|}
\hline \multicolumn{2}{|c|}{ Maddeler } & \multirow{2}{*}{$\begin{array}{l}\mathbf{r} \\
47 \\
\end{array}$} & \multirow{2}{*}{$\frac{\alpha}{96}$} \\
\hline 1. & Sürekli öz değerlendirmede bulunmak & & \\
\hline 2. & Hasta gereksinimlerini karşılamada yetersiz kalındığında danışmanlık istemek & .64 & .96 \\
\hline 3. & Toplumun sağlik ve güvenliğini korumak & .64 & .96 \\
\hline 4. & Toplumdaki kaynakların dağılımını etkileyen politik kararlara katılmak & .56 & .96 \\
\hline 5. & Meslektaşları ile değerlendirmelerde bulunmak & .63 & .96 \\
\hline 6. & Uygulamaya rehberlik edecek standartlar oluşturmak & .68 & .96 \\
\hline 7. & $\begin{array}{l}\text { Öğrenciler için planlanan öğrenme etkinliklerinin gerçekleştirildiği yerlerde standartları geliştirmek ve } \\
\text { sürdürmek }\end{array}$ & .71 & .96 \\
\hline 8. & Uygulama ortamlarını geliştirmek için etkinlikleri başlatmak & .75 & .96 \\
\hline 9. & Bilgi ve becerileri güncelleştirecek eğitimleri araştırmak & .73 & .96 \\
\hline 10. & Sağlık ile ilişkili etkinliklerde aktif yer alarak mesleği geliştirmek & .79 & .96 \\
\hline 11. & Sağlık bakım politikalarının düzenlenmesinde profesyonel hemşirelik kuruluşlarının rolünü kabul etmek & .73 & .96 \\
\hline 12. & Hemşirelik ve sağlık bakımı hizmetlerine adil erişimi sağlamak & .74 & .96 \\
\hline 13. & Farklı kültürlere sahip toplumun sağl1k gereksinimlerini karşılamak için sorumluluk üstelenmek & .75 & .95 \\
\hline 14. & Yaptığı uygulamaların sorumluluk ve yükümlülüğünü üstlenmek & .77 & .95 \\
\hline 15. & Uygulama alanında yeterliliği sürdürmek & .78 & .96 \\
\hline 16. & Hastaların ahlaki ve yasal haklarını korumak & .77 & .96 \\
\hline 17. & Profesyonel değerlere ters düşen etik bir durum olursa bakıma katılmayı reddetmek & .61 & .96 \\
\hline 18. & Hasta savunucusu olarak etkinlik göstermek & .66 & .96 \\
\hline 19. & Uygulamaya yönelik hemşirelik araştırmalarına katılmak ve/veya uygun araştırma bulgularını uygulamak & .77 & .96 \\
\hline 20. & Farklı yaşam biçimine sahip hastalara ön yargısız bakım vermek & .78 & .96 \\
\hline 21. & Hastanın kişisel kişilik hakkını korumak & .79 & .96 \\
\hline 22. & Şüpheli veya uygun olmayan uygulamaları yapan kişilere engel olmak & .76 & .96 \\
\hline 23. & Araştırmaya katılan bireylerin haklarını korumak & .79 & .96 \\
\hline 24. & Doğruluk ve insana saygı ilkelerinin rehberliğinde uygulama yapmak & .79 & .96 \\
\hline 25. & Hastanın gizliliğini sürdürmek & .74 & .96 \\
\hline 26. & Profesyonel hemşirelik kuruluşlarının etkinliklerinde yer almak & .70 & .96 \\
\hline
\end{tabular}


için kullanılabilecek istatistiksel bir yöntemdir. Bu test sonucunda elde edilen chi-square test istatistiğinin anlamlı çıkması verilerin çok değişkenli normal dağılımdan geldiğinin göstergesidir (Büyüköztürk 2004).

\section{Araştırmanın Etik Yönü}

Çalışmaya başlamadan önce HMDÖ-R'nin Türk toplumuna uyarlanması ve kullanılabilmesi için Darlene Weis ve Mary Jane Schank'tan yazılı izin alındı. İstanbul Üniversitesi Cerrahpaşa Tıp Fakültesi Etik Kurulundan etik onay sağlandı. Çalışmanın yürütülebilmesi için okul müdürlüğü ve hastane yönetiminden yaz111 izin alındı. Çalışmaya katılımda gönüllülük ilkesine özen gösterilerek, örneklem grubunu oluşturan hemşireler ve öğrencilerden, çalışmanın amacı, kendilerinden ne beklenildiği ve yasal hakları konusunda bilgilendirme sonrası sözel izin sağlandı. Elde edilen bilgilerin gizli tutulacağı güvencesi verildi.

\section{BULGULAR}

Çalışma örneklemini oluşturan 228 hemşire ve öğrencinin, yaş aralığ 19-54 yıl arasında ve yaş ortalamas1 $26.09 \pm 6.82$ idi. \%98.7'sinin kadın, \%73.7'sinin bekar olduğu saptandi.

Kapsam Geçerliği: HMDÖ-R'nin uzman görüşlerine göre maddelerin büyük çoğunluğunun (\%94.66) "uygun" ve "çok uygun” şeklinde puanlandığı ve KGİ değerinin 0.95 olduğu saptand1.

İç Tutarlık: HMDÖ’nün iç tutarlılığını test etmek için yapılan analizde, Cronbach alfa güvenirlik katsayıs1 0.96 bulundu. HMDÖ-R'nin madde geçerliğine ve homojenliğine ilişkin madde toplam puan korelasyonları incelendiğinde, tüm maddelerin korelasyonları $\mathrm{p}=0.001$ anlamlıl1k düzeyinde olup korelasyon katsayılarının 0.47 ile 0.79 arasında değiştiği belirlendi (Tablo 1).

Zamana göre değişmezlik: Ölçeğin zamana göre değişmezliğini değerlendirmek üzere yapılan test-tekrar test analizinde, Pearson Korelasyon katsayısının 0.90 olduğu ve iki ölçüm arasında yüksek düzeyde ve pozitif yönde istatistiksel olarak anlamlı bir ilişkinin bu-

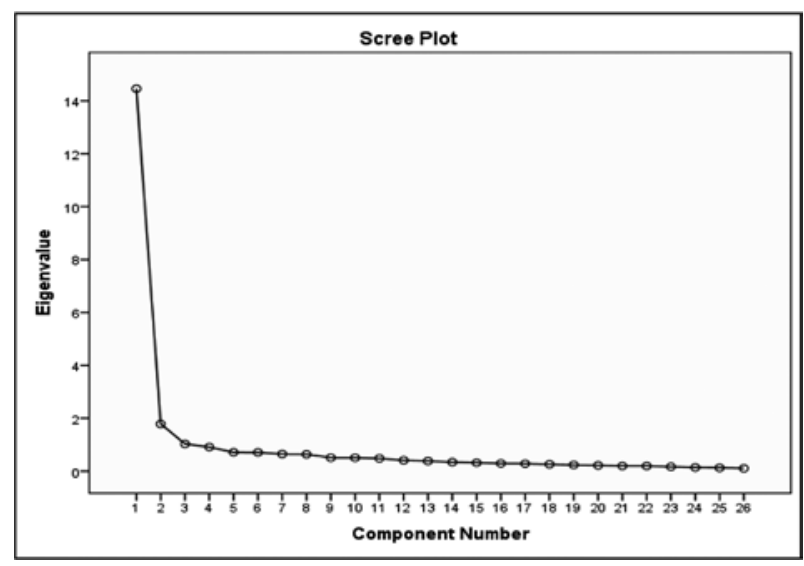

Şekil 1. Özdeğerler Grafiği (Scree Plot).

lunduğu saptandi $(\mathrm{p}=0.000)$. İki hafta ara ile tekrarlanan ölçümler sonucu elde edilen puanlar arasındaki farkın istatistiksel olarak anlamlı olmadığ görüldü $(\mathrm{t}=0.53 ; \mathrm{p}=0.59)$.

Yapı Geçerliği: KMO değeri 0.96, Barlett's testi ki kare değeri $6811.872(\mathrm{p}<0.000)$ bulundu. Varimaks rotasyonu ile yapılan açımlayıcı faktör analizi sonucu ölçek maddelerinin özdeğeri 1'den büyük üç faktör altında toplandığı, tüm maddelerin faktör yük değerlerinin 0.49 ile 0.82 arasında değiştiği saptandı.

Ancak özdeğerlerin grafik dağılımı incelendiğinde (Şekil 1), üç temel kırılma noktasının olduğu ve en keskin kırılmanın birinci faktörden sonra gerçekleştiği saptand. Bu durumda HMDÖ-R'nin, tek boyutlu ve çok faktörlü bir yap1 gösterdiği belirlendi. Özdeğerleri sırası ile $9.43,5.31$ ve 2.51 olan üç faktörlü yapının, toplam varyansın \%66.42'ini açıkladığı gözlendi. Faktörlerin altında yer alan maddelere göre faktörler isimlendirildi (Faktör 1 "Bakım", Faktör 2 "Profesyonellik", Faktör 3 “Güven”). Varimaks rotasyonu sonrası elde edilen faktörlerin açıkladıkları varyanslar, faktör yükleri ve faktörlerle ilişkili maddeler ve faktör isimleri Tablo 2`de sunuldu.

Tablo 3'de görüldüğü gibi HMDÖ-R'den elde edilen toplam puanlarla faktörlere ait puanlar arasındaki korelasyonların 0,75 ile 0,96 arasında değiştiği ve korelasyon katsayılarının 0,01 düzeyinde anlamlı olduğu saptand1. 
Tablo 2. HMDÖ-R'nin Varimaks Rotasyonu

\begin{tabular}{|c|c|c|}
\hline \multicolumn{3}{|c|}{ Sonrası Faktör Analizi } \\
\hline & Madde & $\begin{array}{l}\text { Faktör } \\
\text { yükü }\end{array}$ \\
\hline \multirow{15}{*}{$\begin{array}{l}\text { Faktör 1:Bakım } \\
\text { Özdeğer } 9.43 \\
\text { Varyans \%55.61 } \\
\text { Cronbach Alfa } 0.96\end{array}$} & 21 & .82 \\
\hline & 24 & .82 \\
\hline & 23 & .77 \\
\hline & 15 & .76 \\
\hline & 25 & .76 \\
\hline & 20 & .75 \\
\hline & 22 & .73 \\
\hline & 16 & .73 \\
\hline & 14 & .71 \\
\hline & 12 & .68 \\
\hline & 19 & .66 \\
\hline & 17 & .65 \\
\hline & 10 & .65 \\
\hline & 18 & .63 \\
\hline & 13 & .58 \\
\hline \multirow{8}{*}{$\begin{array}{l}\text { Faktör 2:Profesyonellik } \\
\text { Özdeğer 5.31 } \\
\text { Varyans \%6.85 } \\
\text { Cronbach Alfa } 0.90\end{array}$} & 5 & .77 \\
\hline & 6 & .75 \\
\hline & 7 & .75 \\
\hline & 8 & .74 \\
\hline & 4 & .65 \\
\hline & 9 & .60 \\
\hline & 26 & .59 \\
\hline & 11 & .55 \\
\hline \multirow{3}{*}{$\begin{array}{l}\text { Faktör 3: Güven } \\
\text { Özdeğer } 2.51 \\
\text { Varyans \%3.95 } \\
\text { Cronbach Alfa } 0.77\end{array}$} & 2 & .75 \\
\hline & 1 & .72 \\
\hline & 3 & .54 \\
\hline Toplam varyans $\% 66.42$ & \multicolumn{2}{|c|}{ Toplam Cronbach Alfa 0.96} \\
\hline
\end{tabular}

\section{TARTIŞMA}

Çalışma, Hemşirelerin Mesleki Değerleri ÖlçeğiRevize'nin Türk toplumuna uyarlamasını yaparak,

Tablo 3. Toplam Ölçek - Faktör Korelasyonları

\begin{tabular}{|l|c|c|c|c|}
\hline & A & Toplam Ölçek & Faktör 1 & Faktör 2 \\
\hline Faktör 1 & 0.96 &, $967^{*}$ & & \\
\hline Faktör 2 & 0.90 &, $887^{*}$ &, $756^{*}$ & \\
\hline Faktör 3 & 0.77 &, $758^{*}$ &, $659^{*}$ &, $667^{*}$ \\
\hline *p $<0,01$ & \\
\hline
\end{tabular}

hemşirelik mesleki değerlerini inceleyen çalışmalarda yararlanılmak üzere bir ölçme aracını ülkemiz hemşirelik literatürüne kazandırmak amacı ile gerçekleştirildi. Bir kültüre özgü geliştirilen ölçüm araçlarının, farklı kültürlerde kullanılmadan önce dil eşdeğerliğin sağlanması ve o toplum için geçerli ve güvenilir olup olmadığının test edilmesi gerekir (Ercan ve Kan 2004; Erefe 2002). Bu doğrultuda, öncelikle ölçeğin Türkçe ve İngilizce formlarının dilsel eşdeğerliği, çeviri - geri çeviri yöntemi ile değerlendirildi ve her iki formda da yer alan maddelerin benzeştiği görülerek dil eşdeğerliğinin sağlandığına karar verildi.

Çalışmada, ölçeğin kapsam geçerliği, 10 uzmanın maddelere ilişkin görüşlerinin KGİ ile değerlendirilmesi ile sağlandı. Kapsam Geçerlik İndeksi için önerilen referans değerler dikkate alındığında (Yurdagül 2005), çalışmada 0.95 bulunan KGİ değeri ile Türkçe formun kapsam geçerliğinin uygun olduğu görüldü.

HMDÖ-R'nin iç tutarlığını belirlemek için hesaplanan Cronbach alfa katsayısı (0.96) oldukça yüksek bulunmas1 yüksek güvenirliğe sahip olduğunu gösterdi. $\mathrm{Bu}$ değer, Weis ve Schank (2009)'ın özgün ölçeğin psikometrik analiz çalışmasından, Lin ve Wang (2010)'ın uyarlama çalışmasından elde ettikleri Cronbach alfa değerlerinden daha yüksek bulundu.

HMDÖ-R'nin maddelerinin ölçeğin bütününü temsil gücü ve ayırt ediciliği belirlemek amacı ile yapılan analizde, madde toplam puan korelasyonları .30'un altında kalan maddenin bulunmadığı ve tüm maddelerin $\mathrm{p}=0.001$ anlamlılık düzeyinde korelasyon gösterdiği, korelasyon katsayılarının 0.47 ile 0.79 arasında değiştiği ve değerlerin yüksek güvenirlik düzeyinde olduğubelirlendi (Tablo 1). Bu bulgu Lin ve Wang (2009)'ın sonuçları ile benzerlik gösterirken özgün ölçekten elde edilen madde toplam puan korelasyonlarından daha yüksek bulundu (Weis ve Schink 2009).

İki hafta ara ile 27 öğrenciden elde edilen test-tekrar test korelasyon katsayısı ( $\mathrm{r}=0.90, \mathrm{p}=0.000)$, HMDÖR'nin iki farklı zamanda yapılan ölçümler arasında güçlü bir ilişki olduğunu ve ölçeğin zamana göre değişim göstermediğine işaret etti. Özgün ölçeğin kültürel 
uyarlamasının yapıldığı çalışmalarda zamana göre değişmezlik güvenirliğinin yapılmadığı gözlendi (Hoyuelos ve ark. 2010; Lin ve Wang 2010).

Ölçeğin geçerliğini belirlemek amacı ile yapılan faktör analizi öncesi KMO değerinin kabul edilebilir s1nır olan 0,60'ın üzerinde, oldukça yüksek bir değerde $(0,93)$ bulunmas1, Barlett's testi sonucu $\left(\chi^{2}=6811.872\right.$; $\mathrm{p}<0,01)$ verilerin normal dağılıma sahip olduğu belirlenmesi verilerin faktör analizi için uygun olduğunu gösterdi.

Varimaks rotasyonu ile uygulanan açımlayıcı faktör analizinde, tüm maddelerin faktör yük değerlerinin, eşik yük değeri 0.40 'ın üstünde (0.49 - 0.82) olduğu saptandı. HMDÖ-R'nin özgün ölçekle benzer şekilde tek boyutlu ve çok faktörlü bir yapı gösterdiği belirlendi (Tablo 2). Çok faktörlü yapısı özgün çalışmada beş faktörde toplanırken bu çalışmada farklı bulundu ve üç faktör elde edildi. Bu bulgu Lin ve Wang (2010)'ın sonuçları ile benzerdi. Faktörlere ilişkin varyans ve özdeğerler incelendiğinde, ölçeğin toplam varyansının yeterli olduğu (\%66.42) ve en yüksek varyansin Faktör 1'de olduğu görüldü. Üç faktörün isimlendirilmesi, madde ifadelerinin yorumlanmasının yanı sıra faktörler altında toplanan maddelerin özgün ölçekteki faktörler altında toplanan maddeler ile karş1laştırılması yapılarak gerçekleştirildi. Buna göre Faktör 1'in bakım uygulamalarında hasta bireyin insan ve hasta olarak hakları ile ilgili kaygılar üzerine odaklanan ve insancıllık, özgecilik, adalet değerlerine vurgu yapan ifadelerden oluştuğu ve özgün ölçekte "Bakım" olarak isimlendirilen faktör altındaki 9 maddenin tümünü de içerdiği saptandı. Bu doğrultuda çalışmadan elde edilen Faktör 1" "Bakım verme" olarak isimlendirildi. Faktör 2 altında yer alan maddelerin hemşirenin yeterliği / bütünlüğü ve profesyonel sorumluluklarına işaret eden ifadeleri içerdiği ve özgün ölçekte "Profesyonalizm" olarak isimlendirilen ikinci faktörde toplanan maddelerin tümünü kapsadığı görülerek Faktör 2 "Profesyonellik" olarak etiketlendi. Faktör 3 altında toplanan maddeler incelendiğinde, uygulama alanında yeterliğin sürdürülmesinde hemşirenin yükümlülüğünün yanı sıra adalet ilkesinin sağlanmasına yönelik ifadelerden oluştuğu ve bunların özgün ölçekte "Güven" olarak isimlendirilen faktör maddeleri ile benzeştiği görülerek Faktör 3'de aynı isimle (Güven) etiketlendirildi. Üç faktörün isimlendirilmesi, faktörler altında toplanan maddelerden dolayıLin ve Wang (2010)'ın çalışmasından farklılık gösterdi. HMDÖ-R'nin farklı kültürlere uyarlandığı çalışmalarda da faktör sayısı ve faktörlere yüklenen maddelerin özgün ölçekle uyuşmadığı gözlendi (Lin ve Wang 2010). Orak ve Alpar (2012) tarafından Türk toplumuna uyarlanan özgün ölçeğin ilk uzun versiyonun uyarlama çalışmasında da benzer durumlar yaşandığı belirlendi. Bu durumun ölçeğin duyuşsal yönü baskın olan davranışsal özellikleri içermesinden kaynaklanabileceği düşünüldü (Ercan ve Kan 2004; Gözüm ve Aksayan 2003). Nitekim Hoyuelos ve ark. (2010) 'nın ölçeğin İspanya toplumuna uyarlanması çalışmalarında, yapı geçerliğinin yapılamadığı görüldü.

Özgün ölçeği geliştiren Weis ve Schank (2009)'ın ölçeğin alt boyut içermediğini vurgulamalarına ve ölçeğin tek boyut olarak kullanılmasını önermelerine karşın güvenirlik ve geçerlik çalışmalarında beş faktörlü bir yapı elde ettikleri ve bunların alt boyut / alt ölçek gibi algılanmasına yol açtıkları görüldü. Nitekim bu çalışma da HMDÖ-R'den elde edilen toplam puanlarla faktörlerin puanları arasındaki korelasyonların yüksek ve anlamlı bulunması (Tablo 3), ölçeğin tek boyutlu ve çok faktörlü bir yapıya sahip olabileceğinin kanitı olarak kabul edildi. Diğer taraftan Weis ve Schank (2009)'ın özgün ölçeğin yapısal modellemesinde kuramsal çerçeve ile uyumda yetersiz kaldığını ve ileri çalışmalara gereksinim olduğunu vurgulaması nedeni ile bu çalışmada doğrulayıcı faktör analizi yapılmadı.

HMDÖ-R'nin güvenirlik ve geçerlik çalışmasında dikkati çeken önemli bir nokta özgün ölçeğin hemşirelik etik kodları ile ilişkisini vurgulamalarına karşın Weis ve Schank (2009)'ın ölçek maddeleri ile etik kodlar arasındaki bağlantıyı açıkça göstermemiş olmaları idi. Dolayısı ile çalışmada bu bağlantıyı gösterecek ya da doğrulayacak bir analiz yapılamadı. 


\section{SONUÇ VE ÖNERILLER}

Hemşirelerin Mesleki Değerleri Ölçeği-Revize'nin Türk toplumuna uyarlanması için yapılan analizlerden elde edilen bulgular, ölçeğin Türkçe formunun güvenilir ve geçerli olduğunu gösterdi. Yazarları tarafından özgün ölçeğin alt boyut içermediğini belirtmelerine karşın kendi çalışmalarında da olduğu gibi faktör analizi ile elde edilen ve ölçek-faktör korelasyonlar1nın bağıntısı ile doğrulanan alt faktörlerin ise yapılacak çalışmalarda verilerin yorumlanmasına katkı sağlayabileceği düşünüldü. Bu doğrultuda HMDÖ-R'nin, hemşirelerin ve öğrencilerin, hemşirelik değerlerine ilişkin algılarının incelenmesi, hemşirelik değerlerinin geliştirilmesini hedefleyen programların değerlendirilmesi amacı ile yararlanılabilecek bir araç olduğu ifade edilebilir. Bununla birlikte, ölçeğin kullanılacağı araştırmalarda temel geçerlik ve güvenirlik analizlerinin tekrarlanması önerilir.

\section{KAYNAKLAR}

Aksayan, S., Gözüm, S. (2002). Kültürlerarası ölçek uyarlaması için rehber I: Ölçek uyarlama aşamaları ve dil uyarlaması. Hemşirelik Araştırma Dergisi, 4(1): 9-14.

Babadağ, K. (2010). Hemşirelik ve değerler. 1. baskı, Alter Yayınc1lik, Ankara.

Bademci, V. (2006). Güvenirliği doğru anlamak ve bazı klişeleri yıkmak: Bilinenlerin aksine, cronbach'ın alfa katsayıs1, negatif ve “-1” den küçük olabilir. Eğitim Fakültesi Dergisi, 7(12): 3-26.

Büyüköztürk, Ş. (2008).Veri Analizi El Kitabı. 9. baskı, Pegem Akademi, Ankara.

Ercan, İ., Kan, İ. (2004). Ölceklerde güvenirlik ve geçerlik. Uludağ Üniversitesi Tıp Fakültesi Dergisi, 30(3): 211-216.

Erefe, İ. (Ed.). (2002). Veri Toplama Araçlarının Niteliği.Hemşirelikte Araştırma İlke Süreç ve Yöntemleri. Odak Ofset, İstanbul.

Fahrenwald, N. L. ve ark. (2005). Teaching core nursing values. Journal of Professional Nursing, 21(1): 45-61.

Gözüm, S., Aksayan, S. (2003). Kültürlerarası ölçek uyarlaması için rehber II: Psikometrik özellikler ve kültürlerarası karşılaştırma. Hemşirelik Araştırma Dergisi, 5(1): 3-14.

Hoyuelos, B. S. ve ark. (2010). Nursing professional values: Validation of a scale in a Spanish context. Nurse Education Today, 30: 107-112.

Kuçuradi, İ. (2002). Etik. Metaksan Anonym Şti., Ankara.
LeDuc, K., Kotzer, A. M. (2009). Bridging the gap: A comparison of the professional values of students, new graduates, and seasoned professionals. Nursing Education Perspectives, 30(5): 279-284.

Lin, Y. H., Wang, L. S. A. (2010). Chinese version of the revised nurses professional values scale: Reliability and validity assessment. Nurse Education Today, 30: 492-498.

Martin, P., Yarbrough, S., Alfred, D. (2003). Professional values held by baccalaureate and associate degree nursing students. Journal of Nursing Scholarship, 35(3): 291-296.

Milton, C. L. (2007). Professional values in nursing ethics: Essential or optional in the global universe? Nursing Science Quarterly, 20(3): 212-215.

Orak, N. S., Alpar, Ş. E. (2012). Validity and reliability of the nurses' professional values scale's Turkish version. Marmara Üniversitesi Sağllk Bilimleri Enstitüsü Dergisi, 2(1): 22-31.

Pakizeh, A., Gebauer, J. E., Maio, G. R. (2007). Basic human values: Inter-value structure in memory. Journal of Experimental Social Psychology, 43(3): 458-465.

Polit, D. F., Beck, C. T. (2004).Nursing Research-Principles and Methods. 7. basım, Lippincott Williams \& Wilkins, Philadelphia PA.

Schank, M. J., Weis, D. (2000). Exploring commonality of professional values among nurse educators in the United States and England. Journal of Nursing Education, 39(1): 41-44.

Schank, M. J., Weis, D. (2001). Service and education share responsibility for nurses' value development. Journal for Nurses in Staff Development, 17(5): 226-233.

Shaw, H. K., Degazon, C. (2008). Integrating the core professional values of nursing: A profession, not just a career. Journal of Cultural Diversity, 15(1): 44-50.

Snellman, I., Gedda, K. M. (2012). The value ground of nursing. Nursing Ethics, 19(6): 714-726.

Weis, D., Schank, M. J. (2000). An instrument to measure professional nursing values. Journal of Nursing Scholarship, 32(2): 201204.

Weis, D., Schank, M. J. (2002). Professional values: Key to professional development. Journal of Professional Nursing, 18(5): 271-275.

Weis, D., Schank, M. J. (2009). Development and Psychometric Evaluation of the Nurses Professional Values Scale-Revised. Journal of Nursing Measurement, 17(3): 221-231.

Yurdagül, H. (2005). Ölçek geliştirme çalışmalarında kapsam geçerliği için kapsam geçerlik indeksleri'nin kullanılması. XIV. Ulusal Eğitim Bilimleri Kongre Kitabı, Denizli, 1-6. 